UDC 613.644: 612.842 .5

DOI: $10.21668 /$ health.risk/2021.1.09.eng

Research article

\title{
PHYSIOLOGICAL CRITERIA FOR IMPROVING LABOR INTENSITY CLASSIFICATION USED IN OCCUPATIONAL RISKS ASSESSMENT
}

\section{I.V. Bukhtiyarov, O.I. Yushkova, M. Khodzhiev, A.V. Kapustina, A.Yu. Forverts}

Izmerov Research Institute of Occupational Health, 31 Budennogo Ave., 105275, Moscow, Russian Federation

The paper focuses on results of substantiating and selecting informative physiological criteria that can be used for assessing and controlling functional state and working conditions category taking into account physical and nervous-emotional loads borne by CNC- machinery operators. Basing on complex physiological and ergonomic studies and retrospective data analysis, we showed that workers from various occupational groups who dealt with physical labor had to face certain strain over a working shift. Such strains, given long-term working experience, could result in neuromuscular system overstrain and occupational diseases occurrence.

We substantiated and developed informative physiological criteria that allowed assessing and controlling functional state and working capacity as well as working conditions category taking into account occupational activities.

The present research involved using a set of occupational studies, physiological and ergonomic procedures as well as clinical and statistic ones for examining peculiarities related to functional state of workers' bodies under exposure to occupational factors taking into account specific working tasks and loads. It allowed us to substantiate labor intensity assessment.

Our research results revealed that there was a strong correlation between hand muscles endurance to static exertion (decrease in \% by the end of a work shift) and working conditions category given local and overall muscular loads borne by workers. This criterion is recommended for control over functional state and working capacity taking into account occupational peculiarities and gender-related differences. It is necessary to accumulate scientific data for confirming a similar correlation between overall physical working capacity (OPWC) and working conditions category. Results obtained via physiological research were used for developing prevention activities for workers.

Key words: physiological criteria, classification, labor intensity, physical and nervous and emotional loads, working conditions category, functional state, overstrain, prevention.

At present it is still difficult to predict probable changes in workers' health since there hasn't been sufficient research aimed at determining peculiarities related to how workers' functional systems get overstrained depending on labor intensity at contemporary working places. The necessity to create a classification for labor process factors (labor intensity and hardness) occurred long ago; such a classification should include a table with certain criteria for assessing relevant parameters. The first attempt to create such a classification is considered to be made in a publication issued in 1970 by A.V. Vasilyeva, S.I. Gorshkov, M.A. Gritsevskiy et al., well- known occupational physiologists. Their work was entitled «Physiological and hygienic issues related to work and leisure regimes in industry» and was issued for "Work and leisure regimes and shift schedules in leading industrial branches» workshop [1].

The authors were right to note that from biological point of view labor was an important function performed by a human body and it involved certain physiological costs. Physiological costs of work, that is, a degree of body functional strain during labor, is usually called «labor hardness». The more exact approach to scientific terminology indicates that in this case we should speak about physical hardness

(c) Bukhtiyarov I.V., Yushkova O.I., Khodzhiev M., Kapustina A.V., Forverts A.Yu., 2021

Igor V. Bukhtiyarov - Doctor of Medical Science, Director, Professor, Corresponding Member of the Russian Academy of Sciences (e-mail: ivdukhtiyarov@mail.ru; tel.: +7 (495) 365-02-09; ORCID: https://orcid.org/0000-0002-8317-2718).

Olga I. Yushkova - Doctor of Medical Science, Professor, Chief researcher at the Laboratory for Labor Physiology and Preventive Ergonomics (e-mail: doktorolga@inbox.ru; tel.: +7 (916) 541-20-48; ORCID: https://orcid.org/0000-0002-6704-3537).

Makhmadamin Khodzhiev - Candidate of Medical Science, Doctoral student (e-mail: amin.dok59@mail.ru; tel.: +7 (968) 585-12-95; ORCID: https://orcid.org/0000-0002-5116-2486).

Angelina V. Kapustina - Candidate of Biological Science, Senior researcher at the Laboratory for Labor Physiology and Preventive Ergonomics (e-mail: ft-matuhin@mail.ru; tel.: +7 (903) 542-45-74; ORCID: https://orcid.org/0000-0001-8631-0074).

Anna Yu. Forverts - Junior researcher at the Laboratory for Labor Physiology and Preventive Ergonomics, post-graduate students (e-mail: agniia.forverts@gmail.com; tel.: +7 (903) 201-17-82; ORCID: https://orcid.org/0000-0002-3485-5221). 
and nervous strain any labor involves. It can be substantiated by the following.

Functional strain that appears in a body due to labor can schematically be divided into two parts, energy- and information-related ones. The first prevails in case labor is predominantly physical; the second, predominantly intellectual. Physiologists determine labor hardness as loads on a body occurring due to labor that requires muscle efforts and relevant energy support.

Physiologists determine labor intensity as loads on a body occurring due to labor that requires intensive brain work aimed at obtaining and analyzing information.

Later criteria were developed and included into «Hygienic labor classification (as per adverse and hazardous occupational factors, labor hardness and intensity)» (Moscow, 1986) ${ }^{1}$. Labor conditions and character were differentiated in such a way so that it allowed for an extent to which occupational factors and labor-related factors deviated from the existing hygienic standards and influence they exerted on workers' functional state and health. Three categories of labor conditions and character were determined according to those parameters.

There are scientific grounds for assessing labor developed by hygienists and physiologists, namely «Hygienic labor classification» (1986), the Guide R 2.2.013-94 ${ }^{2}$ last edited in $1999^{3}$, and the valid Guide R 2.2.2006-05 «the Guide on hygienic assessment of occupational and labor-related factors. Criteria and working conditions classification $»{ }^{4}$. These works allow assessing labor intensity as per five types of loads: intellectual, sensory, emo- tional, monotonous, and labor regime. However, at present it is often highlighted that this procedure hardly allows obtaining quantitative assessments since it only provides as opportunity to qualitatively determine intellectual or emotional loads etc. for different durations of a working day, differently organized technological cycles, or instable working places.

Changes in character of labor that is now required at up-to-date working places make it necessary to substantiate quantitative criteria for labor intensity assessment; relevant alterations are to be made into regulatory documents (The Federal Law «On special assessment of working conditions» No. 426-FZ issued on December 28, 2013 and the procedure for accomplishing this assessment) ${ }^{5}$.

Labor intensity is determined according to $R$ 2.2.2006-05 when a sanitary-hygienic profile of worker's labor is created in case a medical specialist believes he or she is suffering from an occupational disease (The Order by the RF Ministry for Public Healthcare and Social Development No. 103 issued on November 10, 2009) ${ }^{6}$.

It is also rather difficult to substantiate informative physiological parameters that allow estimating and controlling workers' functional state and working conditions categories (optimal, acceptable, or hazardous).

Data that are available in literature indicate that being prepared to physical activity (physical proficiency) is significant for maintaining efficient work functions during labor activities [2, 3]. Some authors revealed that physical proficiency that was determined bas-

\footnotetext{
${ }^{1}$ Hygienic labor classification (as per adverse and hazardous occupational factors, labor hardness and intensity). Approved by the deputy to the Chief Sanitary Inspector of the USSR Public Healthcare Ministry A.I. Zaichenko on August 12, 1986 No. 4137-86. Moscow, 1986, 11 p. (in Russian).

${ }^{2}$ R 2.2.013-94. Hygienic criteria for assessing labor conditions as per adverse and hazardous occupational factors, labor hardness and intensity. Approved by the first deputy to the Head of the RF State Sanitary Epidemiologic Surveillance Service on July 12, 1994. Moscow, 1994, 131 p. (in Russian).

${ }^{3}$ R 2.2.755-99. Hygienic criteria for labor conditions assessment and classification as per adverse and hazardous occupational factors, labor hardness and intensity. Approved by the RF Chief Sanitarian Inspector on April 23, 1999. Moscow, 1999, 140 p. (in Russian).

${ }^{4}$ R 2.2.2006-05. The Guide on hygienic assessment of occupational and labor-related factors. Criteria and working conditions classification. The Bulletin of regulatory and methodical documents issued by the State sanitary Epidemiologic Surveillance Service. Moscow, 2005, 142 p. (in Russian).

${ }^{5}$ On special assessment of working conditions: The Federal Law issued on December 28, 2013 No 426-FZ. KonsultantPlus. Available at: http://www.consultant.ru/document/cons_doc_LAW_156555/(03.03.2020) (in Russian).

${ }^{6}$ The instruction on how to draw up a sanitary-hygienic profile of working conditions for a worker who is believed to be suffering from an occupational disease: The Order by the RF Ministry for Public Healthcare and Social Development No. 103 issued on November 10, 2009. StandartGost. Available at: https://standartgost.ru/g/base/1/id054468/\%D0\%9F\%D1\%80\%D0\%B8\%D0\%BA\%D0\%B0\%D0\%B7_103 (03.03.2020) (in Russian).
} 
ing on overall physical working capacity (OPWC) was related to fatigue development, that is, to changes in functional state of a worker's leading body systems ${ }^{7}$ [4-6]. People with high OPWC had less apparent changes in their motor and vegetative functions than those with low OPWC. L.V. Abolian, V.V. Matyukhin et al. examined peculiarities related to functional state formation in people with certain occupations and revealed that workers with «high» OPWC tended to have better functional state of their nervous and muscular apparatus, better adaptive responses, and good cardiovascular system capacity [7-10]. It is assumed that OPWC can be used together with other physiological parameters for assessing functional state and control over working conditions category determined as per ergonomic properties. It is possible that dependence between physical proficiency and a degree of functional changes occurs within certain, and as a rule, average, OPWC range. It would be interesting to test whether this hypothesis is valid within another OPWC range.

Our research goal was to take up-to-date occupations as an example and to substantiate and develop informative physiological criteria that allow estimating and controlling workers' functional state and working capacity as well as working conditions category taking into account occupational activities.

Data and methods. To solve all the tasks set within the present work, we applied occupational studies, physiologic-ergonomic and clinical-statistical research procedures for examining peculiarities related to how workers' functional state is formed under exposure to occupational factors taking labor specifics and labor loads into account. It allowed us to try and substantiate approaches to labor intensity assessment.

We examined practically healthy workers from several occupational groups who had to deal with physical (muscular) and nervousemotional loads in their labor activities. Occupational studies and physiological-ergonomic studies were performed involving five occupational groups being made of males (robotic technological complexes (RTC) operators; $\mathrm{CNC}$ machines operators at civil engineering enterprises; steelmen; high riggers who were mostly labor migrants from southern republics; $\mathrm{CNC}$ machines programmers at stone-working enterprises) and two occupational groups made of females employed at a stone-working enterprise in Moscow (CNC stone-working machine operator and CNC grinder operator). Overall, we examined approximately 200 people aged $30.3 \pm 1.0$, with their working experience being equal to $4.8 \pm 0.2$, who worked in morning shifts (three times during a working day).

Occupational profile for each labor activity was drawn up in accordance with the Guide $\mathrm{R}$ 2.2.2006-05. To assess functional state of the nervous-muscular system, we performed dynamometric measurements of hand power and endurance with the following calculation of maximum working capacity (maintained effort being multiplied by duration of this maintenance). Physical proficiency was determined as per OPWC via PWC 170 test and calculated maximum oxygen consumption.

Cardiovascular system examinations involved determining systolic and diastolic blood pressure $\left(\mathrm{BP}_{\max }, \mathrm{BP}_{\min }\right)$ with subsequent calculation of pulse $\left(\mathrm{BP}_{\mathrm{p}}\right)$ and average dynamic (My) blood pressure, heart rate, stroke and minute heart volumes (SHV and MHV), and overall periphery resistance (PR). BP was registered with mercury sphygmomanometer; central hemodynamics parameters were determined via tetrapolar chest rheography. At the beginning and at the end of work there was a physical load test (bicycle ergometer) with load power being $100 \mathrm{WT}$, and an intellectual load test (addition with switching to another activity). Recovery process was written down during 5 minutes after physical loads and during 3 minutes after intellectual ones.

The study was accomplished in conformity with the International Code of Medical Ethics (1949) and Helsinki Declaration on pre-clinical and clinical studies on humans and animals that was approved upon by the World Medical Association (1964). Prior to the study all the par-

\footnotetext{
${ }^{7}$ Matyukhin V.V., Shardakova E.F., Yushkova O.I., Elizarova V.V., Yamplo'skaya E.G., Poroshenko A.S., Kuz'mina L.P. Influence exerted by labor-related factors. «Ekometria» Encyclopedia. Influence exerted on a human body by adverse and hazardous occupational factors. Moscow, Izdatelstvo standartov Publ., 2004, vol. 1, pp. 344-441 (in Russian).
} 
ticipants got acquainted with its procedure and concomitant risks and gave their written informative voluntary consent to take part in it.

We used conventional variation statistics procedures, namely revealing discrepancies between groups using simple means (as per Student's t-test) and correlation analysis (as per Pearson's procedure). All the data were processed with Statistika 6.0 software package ${ }^{8}$.

Results and discussion. Labor hardness caused by a necessity to maintain a forced working posture, to make a lot of deep body bows, and frequently repeated monotonous hand movements etc. aggravates adverse physiological changes in the nervous-muscular system and musculoskeletal system. It can cause not only a decrease in working capacity but also overstrain and pathology occurrence in these systems [11-13].

We assessed labor hardness for $\mathrm{CNC}$ machines operators; the assessment revealed that such parameters as physical dynamic loads (given in units showing external mechanical work, $\mathrm{kg} \cdot \mathrm{m}$ ) and a quantity of monotonous working movement are within optimal range. However, operators have to bend their bodies a lot during work (more than 200 body bending movements over a shift, hazard category 3.1), and an operator has to spend up to $80 \%$ of his working shift standing (hazard category 3.1). Therefore, we can conclude that a $\mathrm{CNC}$ grinder operator has to face working conditions at a workplace that belong to the $3^{\text {rd }}$ class, $2^{\text {nd }}$ hardness degree (hazard category 3.2): $\mathrm{CNC}$ stone-working machine operator and $\mathrm{CNC}$ operator at civil engineering enterprises, 3.1 hazard category; CNC machine programmer and RTC operator, acceptable working conditions, hazard category 2.0.

Physiological research included examining functional state of the nervous-muscular system as being occupationally significant in providing proper working abilities for workers from the examined occupational groups. We detected a decrease in dynamometric parameters over shift dynamics that became especially apparent by the end of a work shift (Table 1). And an extent to which endurance changed depended on working conditions category.
Thus, endurance practically didn't change in RTC operators during the whole work shift.

A decrease in endurance amounted to $20.4 \%$ in CNC machines programmers; $26.4 \%$, in $\mathrm{CNC}$ stone-working machines operators. As labor became harder and more intense, a decrease in endurance by the end of a work shift grew up to $31.0-33.0 \%(p \leq 0.05)$ and it was higher than physiological standards for body strain under physical labor (the parameter should not exceed $20 \%$ under local and overall muscle loads) (see Table 1). Hand force almost didn't change in the examined groups; therefore, changes in maximum muscular working capacity as another parameter showing functional state of the nervous-muscular system were practically the same as changes in endurance.

We compared two types of equipment used at civil engineering enterprises, CNC machines and RTC; the comparison revealed that working with $\mathrm{CNC}$ machinery resulted in greater fatigue in hand muscles than working with RTC. Endurance to static exertion and maximum working capacity of hand muscles fell authentically among CNC machines operators by $21.3 \%(p \leq 0.01)$ and by $21.6 \%(p \leq 0,05)$ already after 4 hours of and by $24.1 \%(p \leq 0.01)$ and $21.6 \%(p \leq 0.05)$ by the end of a work shift accordingly against the initial level. We also revealed insignificant negative dynamics of dynamometric parameters among operators; it can be due to substantial muscle exertion required to move details manually whereas the same operation is performed by a robotmanipulator when a RTC is used.

Researchers revealed that when a person deals with physical labor regardless of muscle loads character (local or overall), his or her functional state and, accordingly, overall working body strain are closely connected to the leading labor-related factors (labor hardness). Excessive loads lead to early signs of fatigue in workers' nervous-muscular system. When a working experience is substantial, long-term performance of such work tasks can result in overstrain in the nervous-muscular system and in frequent occupational diseases; the higher and more intense are loads on

\footnotetext{
${ }^{8}$ Khalafen A.A.. STATISTICA-6. Statistical data analysis. The $3^{\text {rd }}$ edition. Moscow, Binom-Press Publ., 2007,512 p. (in Russian).
} 
Table 1

Changes in hand muscles endurance to static excretion in workers from the examined occuaptional groups taken in shift dynamics

\begin{tabular}{|l|c|c|c|c|}
\hline \multirow{2}{*}{$\begin{array}{l}\text { Occupational group / working conditions } \\
\text { category as per labor hardness }\end{array}$} & \multirow{2}{*}{ Parameter } & \multicolumn{3}{|c|}{ Examination period } \\
\cline { 3 - 5 } & & Beginning of a shift & Middle of a shift & End of a shift \\
\hline \multirow{2}{*}{$\begin{array}{l}\text { RTC operator at civil engineering enter- } \\
\text { prises / hazard category 1 }\end{array}$} & $M \pm m$ & $18.9 \pm 1.1$ & $18.1 \pm 1.3$ & $17.2 \pm 1.7$ \\
\cline { 2 - 5 } & $P$ & - & $>0.05$ & $>0.05$ \\
\hline \multirow{2}{*}{$\begin{array}{l}\text { CNC machine programmer / } \\
\text { hazard category 2 }\end{array}$} & $\%$ & 100 & 95.7 & 91.0 \\
\cline { 2 - 5 } & $M \pm m$ & $21.1 \pm 1.4$ & $18.3 \pm 1.5$ & $16.8 \pm 1.4$ \\
\cline { 2 - 5 } & $\%$ & 100 & $<0.05$ & $<0.05$ \\
\hline \multirow{2}{*}{$\begin{array}{l}\text { CNC stone-working machine operator / } \\
\text { hazard category 3.1 }\end{array}$} & $M \pm m$ & $20.1 \pm 1.1$ & $17.4 \pm 1.3$ & $14.8 \pm 1.7$ \\
\cline { 2 - 5 } & $P$ & - & $>0.05$ & $<0.05$ \\
\hline \multirow{2}{*}{$\begin{array}{l}\text { CNC machine operator at civil engineer- } \\
\text { ing enterprises / hazard category 3.1 }\end{array}$} & $M \pm m$ & 100 & 86.6 & 73.6 \\
\cline { 2 - 5 } & $P$ & - & $14.9 \pm 1.8$ & $14.4 \pm 1.7$ \\
\hline \multirow{2}{*}{$\begin{array}{l}\text { CNC grinder operator / } \\
\text { hazard category 3.2 }\end{array}$} & $M \pm m$ & $21.1 \pm 1.7$ & $17.2 \pm 1.4$ & $13.3 \pm 1.6$ \\
\cline { 2 - 5 } & $P$ & - & $<0.05$ & $<0.01$ \\
\cline { 2 - 5 } & $\%$ & 100 & 82.0 & 69.0 \\
\hline
\end{tabular}

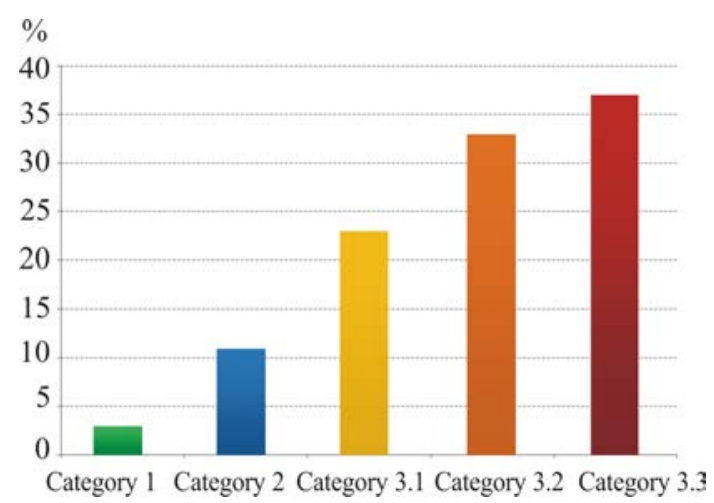

Figure 1. Prevalence of occupational diseases in the nervous-muscular system and musculoskeletal system depending on hazard category as per labor hardness $(\%)$

workers' nervous-muscular system during a work shift, the more probable these negative outcomes become [14-16]. It was convincingly confirmed by results obtained via clinical and functional research. It was established that substantial systematic muscle loads played a potential role in development of occupational diseases with certain etiology. Figure 1 shows prevalence of occupational diseases in the musculoskeletal system depending on labor hardness category.

High physiological strain of the nervousmuscular system that occurs under common physical labor has potential significance for dorsopathy occurrence [17-20]. It was established that systemic overall muscular loads most frequently resulted in such damage to the lumbosacral section as chronic radiculopathy occurrence; it often led to a decrease in occupational working capacity and workers' social deadaptation.

Labor that causes damage to the lumbar spine is most common among builders [21, $22]$. Even in such a well-developed country as Finland up to $20 \%$ workers daily face very grave physical loads despite all technological developments [15]. Multiple studies that focused on health of migrants from the southern republics revealed that as working experience became longer, there was an increase in number of musculoskeletal system disorders; it was caused by such work tasks as lifting and moving heavy weight, working in a forced working posture, etc. Prevalence of such musculoskeletal diseases as, for example, polyosteoarthrosis and polyarthritis, goes down from $32.1 \%$ to $8.9 \%$ (per 100 examined workers) as working experience gets longer; on the contrary, a number of dorsopathy cases grows from 16.8 to $27.0 \%$ among workers with working experience being equal 1-3 years, 7 years, and longer, accordingly. It can be due to substantial physical loads labor migrants have to face.

Results obtained via physiological studies allow considering hand muscle endurance to static exertion to be quite an informative parameter for being used as a criterion when as- 
sessing and controlling functional state and working conditions category in case labor activities involve such loads that labor hardness becomes a leading labor-related factor.

Given hat, Table 2 shows distribution of specific physiological parameters as per working conditions categories (sub-categories) when labor intensity is estimated for different occupational activities.

We also examined another physiological parameter, namely, overall physical working capacity, among CNC machine operator and RTC operators; the examination revealed that there were authentic discrepancies between these two occupational groups as per OPWC and maximum oxygen consumption values. CNC machines operators had average OPWC equal to $25.19 \pm 1.50$; RTC operators, $17.99 \pm$ $0.80 \mathrm{~kg} \mathrm{~m} / \mathrm{min} \mathrm{kg}$ of weight $(p \leq 0.01)$; authentic discrepancies between the groups regarding maximum oxygen consumption were also present $(p \leq 0.01)$.

Assessing workers' physical conditions according to the methodical guidelines ${ }^{9}$ allowed establishing that physical proficiency was above average (high) among CNC machine operators and below average (satisfactory) among RTC operators. These differences seem to be due to labor activities since CNC machine operators have to deal with harder physical labor than RTC operators.

Results obtained via physiologic research revealed that functional state of the cardiovascular system didn't change by the end of a shift in any examined group. At the same time results obtained via tests with loads allowed revealing multi-directional shifts in operators from different occupational groups. SHV curves analysis revealed an adequate response to physical loads among RTC operators both at the beginning and the end of a work shift whereas there was a delayed response among $\mathrm{CNC}$ machines operators. And SHV and MHV didn't recover at the $3^{\text {rd }}$ and $5^{\text {th }}$ minute in CNC machines operators at the end of a work shift after physical loads $(p \leq 0.05)$ and at the $3^{\text {rd }}$ minute after intellectual loads. Periphery resistance as a response to physical loads went down among workers from these two groups and recovery was a bit delayed among CNC machines operators.

CNC machines operators had more apparent responses to physical loads as per BP parameters (maximum, pulse, and average dynamic BP). As we can see from Figure 2, at the beginning of a work shift maximum BP increase authentically more frequently among CNC machines operators against RTC operators $(p \leq 0.05)$. At the $1^{\text {st }}$ recovery minute discrepancies between two groups were substantial $(p \leq 0.05)$, and maximum BP didn't recover at the $3^{\text {rd }}$ and $5^{\text {th }}$ minutes after a test physical load was faced, and at the $1^{\text {st }}$ and $3^{\text {rd }}$ minutes after intellectual loads at the end of a work shift. The same dynamics was detected for pulse and average dynamic blood pressure (see Figure 2).

Comparison made between obtained MHV and PR and physiological standards for the parameters revealed that hyperkinetic

Table 2

Distribution of physiological parameters among workers dealing with physical labor with local and overall loads as per working conditions categories (subcategories) allowing for gender-related differences

\begin{tabular}{|l|c|c|c|c|c|}
\hline \multirow{2}{*}{ Physiological parameter } & \multirow{2}{*}{ gender } & \multicolumn{2}{|c|}{ Wocal and overall loads } \\
\cline { 3 - 6 } & & optimal & acceptable & \multicolumn{2}{c|}{ hazardous } \\
\cline { 3 - 6 } & males & $\leq 20.7$ & $23.8-26.8$ & $26.9-29.9$ & $30.0-33.0$ \\
\cline { 3 - 6 } $\begin{array}{l}\text { Hand muscle endurance to static } \\
\begin{array}{l}\text { exertion (\% of a decrease by } \\
\text { the end of a work shift) }\end{array}\end{array}$ & females & $\leq 21.9$ & $24.3-26.6$ & $26.7-29.0$ & $29.1-31.4$ \\
\hline
\end{tabular}

${ }^{9}$ The Methodical guidelines on assessing physiological standards of human body strain, allowing for genderrelated differences, for different occupational activities (mental, visually strained, physical). Approved on February 26, 2015 by the Scientific Council No. 45 on workers' medical and ecological health issues. Moscow, 2015. (in Russian). 


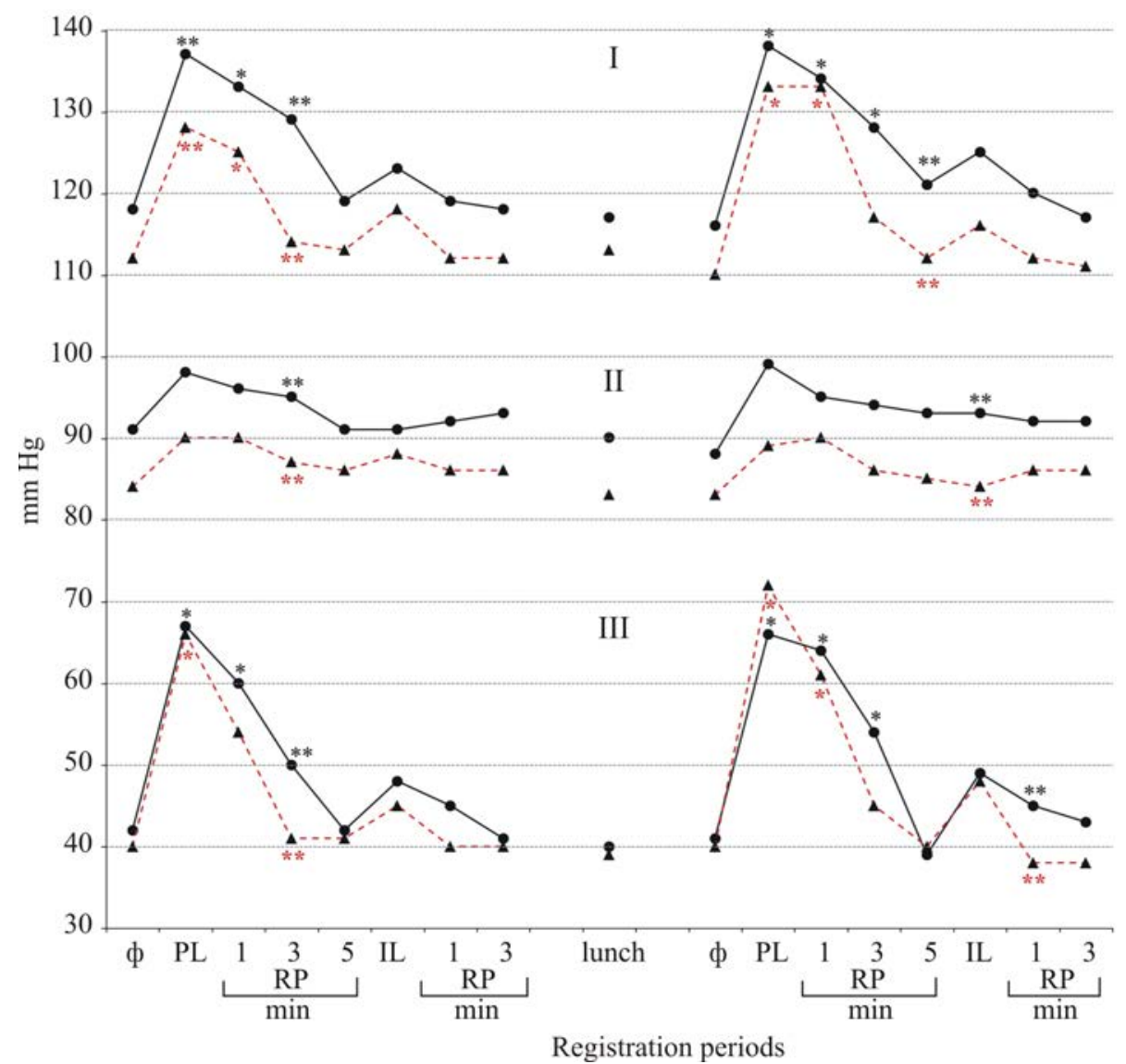

Figure 2. Changes in maximum (I), average dynamic (II), and pulse (III) blood pressure under test loads in operators from two occupational groups

Note: solid line with rounds is for CNC operators; broken line with triangles is for RTC operators; * one asterisk means there are statistic differences form background values; ** two asterisks mean there are authentic discrepancies between the two groups; Y-axis shows blood pressure (mm Hg); X-axis shows registration periods (BP recovery after loads in minutes); $\phi$ means background values; PR is recovery period; PL is physical load; IL is intellectual load.

circulation type ${ }^{10}[23,24]$ prevailed in systemic pressure regulation in operators from the two examined groups. RTC operators tended to have better ration between MHV and RS (an adequate growth and fall in PR under physical loads) that was aimed at optimal circulatory system regulation, in particular, adequate increase in BP. At the same time, CNC machines operators had less apparent changes in MHV and PR with a significant increase in $\mathrm{BP}$ as a response to physical loads and it became especially obvious by the end of a work shift. It indicates there is greater strain in circulatory regulation mechanisms in CNC machines operators. Besides, compensatory mechanisms strain is also more apparent in them that becomes obvious via higher average dynamic blood pressure, and later recovery of $\mathrm{SHV}, \mathrm{MHV}$, and $\mathrm{BP}$ (maximum, pulse, and average dynamic one).

To sum up all the above mentioned, we should note that we detected higher overall physical working capacity among CNC operators and lower OPWC among RTC operators. Labor activities performed by $\mathrm{CNC}$ machines operators involve apparent strain in the nervousmuscular system and it results in early signs (4 hours after a shift started) of developing hand muscle fatigue. Functional state of the cardiovascular system determined as per tests with loads changed more significantly among

\footnotetext{
${ }^{10}$ Instrumental procedures for cardiovascular system examination: a reference book. In: T.S. Vinogradova ed. Moscow, Medistina Publ., 1986, 415 p. (in Russian).
} 
Physiological criteria for improving labor intensity classification used in occupational risks assessment ...

Table 3

A probability that occuaptional pathology might occur (\%) depending on labor hardness and changes in endurance

\begin{tabular}{|c|c|c|c|c|c|}
\hline \multirow{3}{*}{ Parameter } & \multicolumn{5}{|c|}{ Labor hardness } \\
\hline & \multirow{2}{*}{$\begin{array}{c}\text { Category 1, optimal } \\
\text { (slight physical loads) }\end{array}$} & \multirow{2}{*}{$\begin{array}{c}\text { Category 2, acceptable } \\
\text { (average physical loads) }\end{array}$} & \multicolumn{3}{|c|}{ Category 3, hazardous (hard labor) } \\
\hline & & & 3.1 & 3.2 & 3.3 \\
\hline Probability, \% & $0-0.6$ & $6.1-17.0$ & $17.1-28.0$ & $28.1-37.0$ & $\begin{array}{l}\text { Higher than } \\
37.0\end{array}$ \\
\hline \multirow{2}{*}{$\begin{array}{l}\text { Hand muscle endurance } \\
\text { to static exertion, } \% \text { of } \\
\text { a decrease by the end of } \\
\text { a work shift }\end{array}$} & $\begin{array}{c}\text { Males - } \\
\text { lower than } 20.7\end{array}$ & from 20.8 to 23.8 & $\begin{array}{c}\text { from } 23.9 \\
\text { to } 26.8\end{array}$ & $\begin{array}{c}\text { from } 26.9 \\
\text { to } 29.9\end{array}$ & $\begin{array}{l}\text { Higher than } \\
30.0\end{array}$ \\
\hline & $\begin{array}{c}\text { Females - } \\
\text { lower than } 21.9\end{array}$ & from 22.0 to 24.3 & $\begin{array}{l}\text { from } 24.4 \\
\text { to } 26.6\end{array}$ & $\begin{array}{l}\text { from } 26.7 \\
\text { to } 29.9\end{array}$ & $\begin{array}{c}\text { Higher than } \\
31.4\end{array}$ \\
\hline
\end{tabular}

CNC machines operators who had excellent (above average) physical proficiency and it is not in line with conventional opinions. It is known that the greatest decrease in functional capabilities of basic body systems is detected in people with low physical working ability. Obviously, if we want to get an insight into physiological mechanisms behind this phenomenon, we should turn to a regularity established by L.V. Abolyan [7]. He showed in his research that dependence between physical proficiency and functional changes in workers' basic body systems occurred within certain, and as a rule, average, range of overall physical working capacity. When OPWC is «high» as it is the case with CNC machines operators, this dependence doesn't usually hold. Additional studies will be required for understanding this regularity better and for scientific substantiation of OPWC parameter being possibly included as a physiological criterion into assessing and controlling functional state and working conditions category allowing for labor activity type.

Research results revealed that labor hardness was classified as per changes in hand muscle endurance. This endurance parameter is determined as per a decrease in it over a shift measured in $\%$ of its initial value. Distribution of physiological parameters determined for workers dealing with physical labor with local and overall physical loads as pre working conditions categories (sub-categories) taking gender-related differences into account allows assessing probable health risks for workers. We calculated dependence between occupational diseases frequency (2,318 cases were analyzed in retrospect) and labor hardness category under local and overall muscular loads; the calculation allowed determining a regression equation and presenting all the obtained results in Table 3.

All the obtained results indicate that the higher is decrease in endurance, the greater is occupational risk that the above-mentioned pathology occurs. Health disorders are the most probable for workers who have to work under working conditions belonging to the hazard category 3.3; the probability amounts to $37 \%$ in case there is a $30 \%$ decrease in endurance by the end of a work shift among males and a $31.4 \%$ decrease in the parameter among females. Given that, a probability that occupational pathology might occur can be predicted depending on labor hardness category and this prediction can be based on hand muscle endurance to static exertion.

\section{Conclusions:}

1. Research on multiple occupational groups dealing with labor that involved physical and nervously-strained loads allowed establishing that labor-related factors often exceeded acceptable levels for most occupations regardless of load types. Long-term exposure to adverse factors making labor too hard and too intense exerts substantial influence on functional states of workers' body systems, especially, on their nervous-muscular system.

2. Exposure to intense and long-term labor-related factors that exceed acceptable levels (the $3^{\text {rd }}$ hazard category, sub-categories 1-2) results in overstrain occurrence in most workers; this overstrain becomes obvious via substantial changes in physiological parameters taking gender-related differences into account.

3 . Workers dealing with physical labor that involved both local and overall muscular loads tended to have a strong correlation between hand muscle endurance to static exertion $(\%$ of a decrease by the end of a work shift) and working 
conditions category. It allows recommending this parameter for control over functional state and working ability taking into account labor activity type and gender-related differences.

4. Damage to the lumbar spine as an outcome caused by hard working conditions (weight moving and lifting, working in a forced working posture, etc.) is widely spread among builders including labor migrants for the southern republics. A number of musculoskeletal diseases grows as working experience gets longer.

5. We detected that $\mathrm{CNC}$ machines operators tended to have higher overall physical working capacity (OPWC) than RTC operators who had only satisfactory OPWC. Workers with higher OPWC tended to have higher functional capabilities of the nervous-muscular system and apparent strain in circulatory regulation mechanisms when tests with loads were performed.

6. Additional studies are required and obtained data are to be analyzed for revealing dependence between high physical proficiency and functional state of a body and a possibility to use OPWC as a criterion for assessing functional state and working conditions category taking labor activity type into account.

7. Research results allowed establishing a possibility to predict occupational diseases in workers dealing with physical labor as per such a physiological parameter as hand muscle endurance to static exertion. The greater is a decrease in endurance, the higher is a probability that an occupational pathology might occur. Distribution of physiological parameters obtained for workers dealing with physical labor involving local and overall muscular loads as per working conditions categories (sub-categories) taking gender-related differences into account allows assessing health risks for workers.

Funding. The research was not granted any sponsor support.

Conflict of interests. The authors declare there is no any conflict of interests.

\section{References}

1. Vasil'eva A.V., Gorshkov S.I., Gritsevskii M.A. Fiziologicheskie i gigienicheskie voprosy rezhimov truda $\mathrm{i}$ otdykha $\mathrm{v}$ promyshlennosti [Physiological and hygienic issues related to work and leisure regimes in industry]. Rezhimy truda i otdykha i grafiki smennosti $v$ vedushchikh otraslyakh promyshlennost: Materialy simpoziuma. In: V.V. Kulemin ed. Moskva - Ivanovo, 1970, 177 p. (in Russian).

2. Matyukhin V.V., Bukhtiyarov I.V., Yushkova O.I., Shardakova E.F., Kalinina S.A., Elizarova V.V., Yampol'skaya E.G., Poroshenko A.S. Sovershenstvovanie kriteriev otsenki perenapryazheniya i garmonizatsiya standartov fizicheskoi rabotosposobnosti u rabotnikov sovremennykh form truda [Developing criteria for assessing overstrain and harmonizing standards for physical working capacity in workers employed in contemporary working conditions]. Aktual'nye problemy meditsiny truda: sbornik trudov instituta. In: I.V. Bukhtiyarov ed. Moscow, OOO «Melga» Publ., 2015, pp. 38-90 (in Russian).

3. Gridin L.A., Ikhalainen A.A., Bogomolov A.V., Kovtun A.L., Kukushkin Yu.A. Metody issledovaniya i farmakologicheskoi korrektsii fizicheskoi rabotosposobnosti cheloveka [Research procedures and procedures for pharmacological correction of human working capacity]. In: I.B. Ushakov ed. Moscow, Meditsina Publ., 2007, 104 p. (in Russian).

4. Theorell T., Perski A., Akerstedt T., Sigala F., Ahlberg-Hultén G., Svensson J., Eneroth P. Changes in job strain in relation to changes in physiological state. Scand. J. Work Environ. Health, 2013, vol. 14, no. 3, pp. 189-196. DOI: 10.5271/sjweh.1932

5. Anishchenko V.S., Kislitsyn Yu.L., Permyakov I.A. Monitoring rezervov fizicheskoi rabotosposobnosti zdorov'ya studentov [Monitoring over reserves of students' health and its physical working capacity]. Uspekhi i perspektivy fiziologii truda v tret'em tysyacheletii: materialy konferentsii. Moscow, 2001, pp. 25-27 (in Russian).

6. Kosorotova N.S., Reshetenko I.N., Bulavina M.V. Otsenka rabotosposobnosti u rabotnikov, zanyatykh tyazhelym fizicheskim trudom. Professional'noe zdorov'e i trudovoe dolgoletie: materialy Mezhdunarodnoi nauchno-prakticheskoi konferentsii. Shakhty, 2018, pp. 94-95 (in Russian).

7. Abol'yan L.V. Znachenie urovnya obshchei fizicheskoi rabotosposobnosti v razvitii utomleniya rabotayushchikh v usloviyakh professional'noi gipokinezii [Importance of overall physical working capacity and developing fatigue among workers under exposure to occupational hypokinesia]. Gigiena truda i professional'nye zabolevaniya, 1982, no. 10, pp. 14-18 (in Russian).

8. Matyukhin V.V., Bukhtiyarov I.V., Yushkova O.I., Shardakova E.F., Yampol'skaya E.G., Elizarova V.V., Poroshenko A.S., Kapustina A.V. [et al.]. Labor physiology role in workers of different type 
labor activity workability and health. Progress and prospects. Meditsina truda i promyshlennaya ekologiya, 2013, no. 6, pp. 19-24 (in Russian).

9. Yampol'skaya E.G., Shardakova E.F., Elizarova V.V. Izuchenie vzaimosvyazi urovnya obshchei fizicheskoi rabotosposobnosti i pokazatelei zabolevaemosti [Examining a correlation between overall physical working capacity and morbidity]. Psikhofiziologicheskie aspekty trudovoi deyatel'nosti: vserossiiskii sbornik nauchnykh statei. Tver', 2002, pp. 43-49 (in Russian).

10. Matyukhin V.V., Elizarova V.V., Shardakova E.F., Yampol'skaya E.G. Risk factors of functional disorders in mental workers. Meditsina truda i promyshlennaya ekologiya, 2009, no. 6, pp. 1-6 (in Russian).

11. Shardakova E.F., Yushkova O.I., Elizarova V.V., Lagutina G.N. Physiological evaluation of physical and nervous-mental overloads in medicine of labor. Vestnik Tverskogo Gosudarstvennogo Universiteta. Seriya: Biologiya i ekologiya, 2018, no. 3, pp. 7-20 (in Russian).

12. Danilov A.N., Bezrukova G.A., Novikova T.A. Work hardiness as a determinant of occupational health risk in agricultural workers. Meditsina truda i promyshlennaya ekologiya, 2017, no. 9, pp. 59 (in Russian).

13. Merkulova A.G., Kalinina S.A., Bogdanova V.E. Dynamic study of the nervous muscular system of machine operator at the engine make. Meditsina truda i promyshlennaya ekologiya, 2019, vol. 59, no. 9, pp. 695-696 (in Russian).

14. Punnett L., Prüss-Utün A., Imel Nelson D., Fingerhut M.A., Leigh J., Tak S.W., Phillips S. Estimating the global burden of low back pain attributable to combined occupational exposures. Am. J. Ind. Med., 2005, vol. 48, pp. 459-469. DOI: 10.1002/ajim.20232

15. Bruce P., Bernard M.D. Musculoskeletal disorders and workplace factors: A critical review of epidemiologic evidence for work-related musculoskeletal disorders of the neck, upper extremity and low back. U.S.A.: U.S. Department of health and human services Public Health Service Centers for Disease Control and Prevention National Institute for Occupational Safety and Health Publ., 1997, 590 p.

16. Ariëns G.A., Van Mechelen W., Bongers P.M., Bouter L.M., Van der Wal G. Physical risk factors for neck pain. Scandinavian Journal of Work, Environment \& Health, 2000, vol. 26, no. 1, pp. 17-19. DOI: 10.5271/sjweh.504

17. Musculoskeletal disorders and the workplace: Low Back and Upper Extremities. National Research Council and the Institute of Medicine. Washington, 2001, pp. 492. DOI: 10.17226/10032

18. Haakkanen M., Viikari-Juntura E., Martikainen R. Incidence of muscular-sceletal disorders among newly employed manufacturing workers. Scand. J. Work Environ Health, 2001, vol. 27, no. 6, pp. 381-387. DOI: $10.5271 /$ sjweh.630

19. Heliovaara M. Work load and back pain. Scand. J. Work Environ Health, 1999, vol. 25, no. 5, pp. 385-386. DOI: $10.5271 /$ sjweh.450

20. Maksimenko L.V., Yakovenko I.A. Backache risk in dentistry workers. Meditsina truda i promyshlennaya ekologiya, 2017, no. 9, pp. 118 (in Russian).

21. Khodzhiev M., Shardakova E.F., Elizarova V.V. Assessing functional state of labor migrants engaged into construction works. Meditsina truda i promyshlennaya ekologiya, 2017, no. 9, pp. 207 (in Russian).

22. Prokopenko L.V., Shardakova E.F., Yampol'skaya E.G., Elizarova V.V., Lagutina A.V. Integrated physiological-hygienic evaluation of labor in leading professional groups under modern technologies of constructing activities. Vestnik Tverskogo Gosudarstvennogo Universiteta. Seriya: Biologiya i ekologiya, 2014, no. 1, pp. 65-74 (in Russian).

23. Khodzhiev M. Cardiovascular features and adaptable opportunities of the first course university students organism. Vestnik Tverskogo Gosudarstvennogo Universiteta. Seriya: Biologiya i ekologiya, 2016 , no. 3, pp. 18-27 (in Russian).

24. Tsfasman A.Z., Alpaev D.V. Tsirkadnaya ritmika arterial'nogo davleniya pri izmenennom sutochnom ritme zhizni [Circadian rhythms of blood pressure in case daily rhythms have been changed]. Moscow, Reprotsentr Publ., 2011, 144 p. (in Russian).

Bukhtiyarov I.V., Yushkova O.I., Khodzhiev M., Kapustina A.V., Forverts A.Yu. Physiological criteria for improving labor intensity classification used in occupational risks assessment. Health Risk Analysis, 2021, no. 1, pp. 90-99. DOI: 10.21668/health.risk/2021.1.09.eng

Received: 18.01.2021

Accepted: 07.02.2021

Published: 30.03.2021 